\title{
Study the Role of the Corona Crisis in the Unity of the Countries of the Islamic World
}

\author{
Amirreza Emami1 ${ }^{1}$ Fatemeh Zare ${ }^{2}$ \\ ${ }^{1}$ Graduate of Political Science (International Relations), Department of Law and Political Science, Faculty of Social \\ Sciences and Humanities, Yazd, Yazd University, Iran. https://orcid.org/0000-0002-6313-6189. \\ ${ }^{2}$ Graduate of Political Science (International Relations), Department of Law and Political Science, Faculty of Social \\ Sciences and Humanities, Yazd, Yazd University, Iran. https://orcid.org/0000-0002-2410-3800.
}

Corresponding author: Amirreza Emami

\begin{abstract}
With the outbreak of coronary heart disease in early 2020, the pandemic spread to all countries of the world, and governments saw the only solution to this epidemic as high global determination in the form of cooperation. Thus, with the spread of the coronavirus in the world, a new era emerged in the foreign policy of governments and the importance of cooperation and unity in the face of a global epidemic for governments became more prominent. This pandemic also spread to Islamic countries and the Islamic world. The only way to deal with this pandemic was more cooperation and unity, and the countries of the Islamic world also emphasized this. But according to the research findings, the Islamic countries and the countries of the Islamic world only emphasized the solidarity and sympathy of the countries of the Islamic world theoretically. In fact, they potentially emphasized cooperation and unity, but in practice, no activities based on cooperation and unity have been observed. Also, due to the characteristics of this crisis, countries are more seeking to equip and strengthen themselves, and according to the Organization of Islamic Cooperation, Islamic countries through the economy and the implementation of restrictive trade and financial policies, continue to try to advance the economy. They have their own country to be able to face this crisis. The research method is qualitative and is based on the description of the analysis.
\end{abstract}

Keywords: Crisis; coronavirus; Pandemic; Unity; Countries of the Islamic world

\section{Introduction}

When the Corona virus broke out in 2020 and spread around the world, people and governments around the world did not expect the disease to spread to such an extent that thousands of people would die. When the Corona epidemic spread to all countries of the world, governments saw the only solution to the epidemic as high global determination in the form of cooperation. Thus, with the spread of the coronavirus in the world, a new era in the foreign policy of governments emerged and the importance of cooperation and unity in the face of a global epidemic for governments became more prominent. The disease, which also has a high rate of transmission, has spread to most parts of the 
world, affecting all countries of the world. The countries of the Islamic world are also involved in this crisis, each of which is facing this crisis according to its own circumstances. The countries of the Islamic world also realized that the way to deal with this disease, in addition to the special facilities and capacities that each country applies in the face of it, requires more cooperation. Therefore, according to the above explanations, the main question of the research is what is the role of the corona crisis in the unity of the countries of the Islamic world? The importance of this research is that by describing and analyzing this issue, the role of this crisis in the unity of the countries of the Islamic world is explained.

\section{Research Method}

Qualitative research; Qualitative research has a holistic, interpretive approach and is done for exploration in a natural field that should not be done in an artificial range. Qualitative research acquires information about life, culture, value, ideological and behavioral principles, language, feelings, emotions and beliefs of people. A qualitative researcher must put aside his personal values, feelings and prejudices and experience the world through the eyes of others, which is not an easy task. A qualitative researcher collects information using regular methods, thinks about its meaning and concept, concludes, evaluates them, and finally presents them. This process is not performed optimally, unless the qualitative research methodology is strictly observed. The research environment is in fact the real world in which research and study take place. This environment is studied as a whole and its analysis into components and study of components is avoided. In qualitative research, the researcher who plans to collect data must be consistent with the type of information he or she seeks. Provides three strategies of in-depth interview, observation and sampling that the researcher can use in their research. But we can also refer to the study of documents, graffiti and in general stable and unstable documents (Abedi and Shavakhi, 2010).

Descriptive-analytical research; In addition to illustrating what is, the researcher explains the reasons for how it is and why the situation of the problem and its dimensions. The researcher needs a strong argumentative basis to explain and justify the reasons. This support is provided by searching the literature and theoretical topics of research and compiling general propositions and theorems about it, which are usually formulated in the chapter on backgrounds and theoretical topics of research. The researcher logically relates the details of the research problem to the relevant general propositions and draws conclusions. It is important to note that each of these studies has scientific value in its own right. One of the characteristics of descriptive research is that the researcher does not interfere in the situation, situation and role of variables and does not manipulate or control them and only studies what exists, describes and describes it. Also, descriptive research may lead to the discovery of laws and the presentation of theories; This means that general knowledge is gained through such research. For example, when the characteristics of a particular phenomenon or subject are carefully studied and identified, these characteristics can be generalized to similar cases and a general theorem can be presented. Also, in another way, it is possible to achieve general cognitions and theorems through descriptive research, and that is the use of inductive method; This means that when a common and uniform feature or attribute is repeated and observed in various phenomena and objects, it can be expressed and theorized based on it. Of course, such a theory may in some cases be contradicted, lose its validity, or, conversely, be stable. According to the above explanations, the method of the 
present study is qualitative and based on analytical descriptive. The method of data collection and information is based on documentary studies, libraries and reputable research and extension science journals and various statistics.

\section{Theoretical Foundations}

Convergence theories (communications, functionalism, neo-functionalism, and federalism) are often used when talking about the unity of the countries of the Islamic world. Since the end and result of the theories of convergence, peace, tranquility, unity and unity and also the subject of the present study is related to the unity of the countries of the Islamic world. It seems that the theory of convergence can cover the theoretical framework of the research, so in this research, the theory of convergence (Karl Deutsch communication) is used. Of course, it should be noted that the basis of convergence theories is usually influenced by economic and political components and its extension to other areas. Therefore, this study, in order to show the path of sustainable convergence and unity, with one turn, has based the convergence on the foundations of critical considerations (crisis theory) that can be extended to other areas. Therefore, in the theoretical framework of this research, two theories have been used; Convergence theory (Karl Deutsch communication) and crisis theory (Rosenthal).

\section{Convergence}

Convergence is a term that is conceptually opposed to divergence and is typically used in the humanities. Convergence is defined in the Oxford Dictionary in two ways. Combining two things together so that one becomes an inseparable part of the other. Another definition is the full membership of an individual in a society (Velayati and Saeed Mohammadi, 2010) but convergence in political science is the process by which governments or political units to achieve their common goals, voluntarily and consciously, part of the government And they transfer their supreme authority to a transnational center (Kazemi, 1991). In other words, convergence refers to a situation in which the social, economic, political, security, and communication apparatuses of the various units come closer together by eliminating divisive factors and nationalist prejudices in favor of common goals and common interests. That a new system of relations replaces the previous system (Velayati and Saeed Mohammadi, 2010).

Contemporary Western thinkers, often inspired by the fundamental tenets of functionalism, have turned to the theory of cooperation and solidarity to achieve lasting peace. Believing that war and bloodshed are the direct result of the unjust system governing international relations, they consider nationalism, monopoly and other forms of separation of nations as the source of international differences and disorder (Kazemi, 1991). Undoubtedly, theories of convergence, especially the theories of Ernst Haas, have played an effective role in the convergence of European countries (Frankel, 2000). Communication, functionalism, neo-functionalism and federalism are some of the theories that most contemporary thinkers have presented their theories about convergence within the framework of these theories (Velayati and Saeed Mohammadi, 2010). 


\section{Karl Deutsch Communications}

One of the theories of convergence is the theory of communication. The main emphasis of the proponents of this theory is on political, economic, social and cultural exchanges. They believe that increasing countries' exchanges increases their solidarity, which ultimately leads to convergence. The spread of communication at the global level creates a collective and international identity, which is sometimes considered from nationalism to globalism. According to Deutsch, convergence is a situation in which the people of a region resolve their problems peacefully while avoiding the use of force and violence in international relations. The main emphasis of the proponents of this theory is on political, economic and social exchanges in addition, they support the formation and development of organizations capable of bringing about peaceful change and peace (Tylor, 1968). According to him, the characteristic of all human societies is the large volume of exchanges between them. In addition to exchanges, he emphasizes the connections between nations and its role in convergence. According to Deutsch, as the volume of exchanges between nations increases over a relatively long period of time, new communities based on shared identities are formed, which can eventually lead to a superpower (Deutsch, 1979).

Karl Deutsch, as the main theorist of the communication approach in international relations, believes that the intense flow of communication between nations and states can gradually lead to the emergence of a global political-society. Deutsch looks at the pattern of common objective interests. According to Deutsch, communication plays a big role in the proximity of communities, so the more communication in the fields of transport, tourism, postal services, trade and immigration, the closer these communities become to each other and to cooperation instead of conflict. They turn and form security communities. Therefore, with the comprehensive expansion of communication, convergence is achieved. Karl Deutsch defines convergence as the transformation of formerly independent units into coherent military components (Deutsch, 1969).

According to Deutsch, conditions for convergence are necessary. Such as; Consistency of core values, existence of a distinctive and attractive lifestyle such as Asian lifestyle; Expecting more profitable economic ties; Increase the political capacity of the member units of the convergent institution; Superior economic growth of at least some units; Existence of social relations between units; Reciprocity of rewards in the course of communication and exchanges between units; Predictability of units' behavior for each other. According to Deutsche, processive is formed in the course of history. This process begins with a central core that includes one or more larger, more advanced, and stronger political units, and their leaders act as the decision-making elites in the converging system. According to Deutsch, the process of change should move towards full communication (Mottaqi et al., 2015). Of course, Deutsch considers the final stage of convergence to be the formation of a security plural (pluralistic and integrated) (Deutsch, 1957).

\section{Crisis theory}

According to the famous crisis theorist Rosenthal, international crises may be caused by nature or humans. In his view, man-made crises refer to public actions aimed at shaking the social and political context of the international system. Rosenthal defines crisis as follows; Crisis poses a serious threat to the fundamental structures or values and norms of a social system, as a result of which the social 
system must make vital decisions under time pressure and largely unpredictable situations (Rosenthal, 1988). But in order to recognize crises, the concept of the system must first be well clarified. The concept of the system, whether at the international or regional level, is a set of interacting units that, due to their interdependence, are integrated and interconnected and interact with each other. By this definition, a crisis can be described as a situation that can lead to a change in the system and upset its existing balance. In other words, the crisis is a situation in which the process of transformation in the system is such that the continuity and balance of the system is severely endangered and with uncertain results. The need to act as soon as possible to restore it or restore order is felt (Mostaghimi, 1994).

In defining crisis, Rosenthal refers to it as a phenomenon that may facilitate desirable change or reform. In his view, crises should not be considered as inapplicable and undesirable deviations; Rather, it should be considered as part of socio-political dynamics; Because crises test existing policies and formal structures. Thus, the crisis in international relations is a two-dimensional phenomenon, one of which is problems and threats, and the other is a chance for the parties to the crisis. By this definition, Rosenthal sees crises as constructive destructive ones that collapse existing structures and offer new perspectives. And in the meantime, threats can be turned into opportunities that owe to the important and key category of crisis management (Rosental and Comfort, 2001).

\section{Characteristics of international crises}

According to Rosenthal's definition of crisis, as well as in order to determine whether a threat can be considered a crisis, the best way is to describe the characteristics of the crisis. Any threat that has the following three characteristics can be considered as a crisis (Rasouli Saniabadi, 2013). In general, these features include;

- Surprise and sudden appearance of a situation: In any crisis, there is often an element of surprise (although it should be noted that some analysts do not consider surprise as a necessary condition for creating a crisis); An example of this is the sudden invasion of Kuwait by Iraq. This attack, which was a sudden action, eventually led to an international and regional crisis (Rasouli Sani Abadi, 2013)

- Endangering important goals or threatening core values: The severity of the threat depends on the value of what is being threatened. This in itself is enough to imagine and direct perception of decision makers what they consider valuable and vital (Mostaghimi, 1994).

- Time constraint: One of the most important characteristics of any crisis is time constraint. Time constraints or time pressures are related to the short time to make timely decisions. Of course, it should be noted that short time is not always a necessary feature for a crisis. Because there have been crises - like the Moroccan crisis) that have lasted for months or years (Brecher and Wilkenfeld, 1988)

- High degree of likelihood of war: Not every crisis necessarily leads to war, but usually in any crisis with a high threat, the potential for war is very high (Brecher and Wilkenfeld, 1988).

- Necessity of decision-making: One of the main characteristics of any crisis, including international crises, is the necessity of decision-making by the main decision-makers of the unit involved in the crisis. This decision has a lot to do with how the crisis is managed. A decision that despite the lack of information and uncertainty should be accompanied by 
maximum gains and minimum losses and preserve the main interests of the unit in the best way (Rosenthal and T. Hart, 2002). Of course, there are other factors that can be raised; Uncertainty and lack of information, increasing the intensity of interaction, disrupting the order of the international system (Rasouli Saniabadi, 2013).

\section{Divergence, convergence and unity of the countries of the Islamic world}

\section{Islamic world}

The Islamic world includes countries where the majority of its people have converted to Islam, as well as areas inhabited by Muslim minorities.

In other words, the Islamic world includes areas of the planet where Islamic law and sharia rules exist, at least among the people, and manifestations of Qur'anic beliefs can be seen in the culture, customs, teachings, and relationships of the people. The Islamic land is different from the Muslim areas. In Islamic countries, in addition to the Muslim majority, Islam is recognized as an official religion in their constitution. But in Muslim areas, this feature does not exist and only the effects of Islam can be seen in the individual and social behavior of Muslims. They may be in political and cultural conflict with the central government and may be threatened and pressured. In fact, the Islamic world refers to the regions that have accommodated people who believe in Islamic principles and includes all members of this school, regardless of color, skin, soil, race, language, etc. (Goli Zavareh, 2006).

The geographical territory of the Islamic world, which has a majority population of more than $50 \%$ Muslims, can be divided into 11 geographical regions as follows: 1. Southeast Asia: including the Philippines, Brunei, Indonesia, Malaysia, Singapore; 2. South Asia: including Bangladesh, Pakistan, Maldives and Muslim parts of India. 3. Iranian Plateau: including Iran, Afghanistan and Kashmir. 4. Central Asia: including Turkmenistan, Tajikistan, Uzbekistan, Kazakhstan, Kyrgyzstan and parts of western China (Xinjiang). 5. Caucasus and Turkey: including Azerbaijan, Turkey, Chechnya and Dagestan, and parts of Cyprus and Georgia. 6. Southeast Europe: including Albania, Bosnia and Herzegovina. 7. North Africa: including Egypt, Algeria, Libya, Tunisia, Morocco and the Sahara. 8. East Africa: including Somalia, Sudan, Ethiopia, Eritrea, Tanzania, Comoros, etc. 9. West Africa: including Mauritania, Senegal, Guinea, Sierra Leone, Gambia, Ivory Coast and Nigeria. 10. Central Africa: including Mali, Chad, Niger and Burkina Faso (Upper Volta). 11. Arabian Peninsula: including Saudi Arabia, Iraq, Syria, Lebanon, Jordan, Palestine, Yemen, United Arab Emirates, Qatar, Bahrain, Oman and Kuwait (Hafeznia, 2000: 245-245).

\section{The need for convergence and unity}

Although the desire for unity and solidarity throughout history has always been one of the most effective ways to confront the common enemy and achieve certain goals, the tendency to converge on a new type is one of the salient features of the twentieth century, especially the last half century. Economic and technical competition is one of the salient features of the contemporary world and no country can avoid its effects. It is in the context of this competition that cooperation and convergence 
find meaning. Apart from the United States, the issue of convergence has not been studied and pursued in any part of the world as much as in Western Europe. The European Union has always been a pioneer in regional convergence and has even achieved great success in this field, to the extent that other parts of the world are trying to follow the path of Europe and follow the path of convergence by following the example of this group.

Since the formation of the European Union, some Islamic states with common goals have tried to follow suit, following the example of the European Union. In fact, these governments presented various plans for regional cooperation and convergence, some of which were implemented and others remained in the proposal stage. Islamic countries, which have always faced various political, economic and security challenges, like European societies, need new methods such as convergence and the formation of transnational societies to increase the level of national power and solve common problems. The Islamic world as a regional system has many connecting factors, including geographical connectivity, geopolitical capabilities, common external threats, trade and economic capabilities, and religious and cultural homogeneity. The mentioned factors provide the opportunity for Islamic countries to use the model appropriate to the conditions in the Islamic world, to provide the basis for creating unity and convergence among themselves (Velayati and Saeed Mohammadi, 2010).

\section{Divergence and convergence (communication) in the countries of the Islamic world}

The Islamic world is made up of multiple and independent countries, each with its own interests. The plurality of states is the rule of the political world. What makes this rule difficult is the conflict of interests of governments, which if not properly resolved will cause governments to diverge (Yousof zadeh and Khavari, 2019). Despite the efforts of Muslim thinkers and thinkers who have taken an approximate approach to the coexistence of Muslim sects and religions, there is a gap in the convergence of the Islamic world with the desired point. Although the pioneers of the past decades have spent all their efforts in this field, but unfortunately did not achieve all their goals. The situation in the Middle East and what is now being seen in Islamic countries in divergences and distances is the result of factors and harms that indicate the failure of efforts to unite. In order to be able to minimize the level of divisive injuries in the future and provide the ground for maximum convergence, these factors and injuries must first be identified and autopsied. In the field of divisive factors and lack of convergence, different divisions have been presented by researchers (Abbasi, 2015). Safar Abbasi in his research considers these factors in two dimensions of internal barriers (factors within the Islamic world such as various contents of jurisprudence, political and social barriers) and external barriers (external barriers such as enemies of Islam, colonization of Islamic countries and sovereignty). Non-religious on Islamic countries) (Abbasi, 2015).

As mentioned, according to Karl Deutsch's theory, there must be conditions for convergence to occur, some of which are mentioned here;

- Compatibility of core values; The most important main value that exists in the countries of the Islamic world is the existence of religious (Islamic) principles that exist in all countries of the Islamic world. It is true that there are different branches of Islam in these countries, but the main structure and the main axis of society and government of Islamic countries is the 
religion of Islam. Of course, there are other values that are compatible in most countries of the Islamic world, but the most important and central principle of compatibility between the countries of the Islamic world is the religion of Islam.

- The lifestyle of the countries of the Islamic world is different from each other. It is true that the lifestyle of all these countries is based on religious principles and values, and even the Asian lifestyle dominates the relations between nations, but since the lifestyle depends on various factors such as geography, culture and history, etc. Different lifestyles can be observed.

- Expecting more profitable economic ties; Countries are willing to cooperate and consequently converge if this cooperation is profitable and beneficial for them in various dimensions such as the economy. Therefore, according to statistics, we can explain the willingness of countries to cooperate between Islamic countries in the economic field. According to the statistics published by the Organization of Islamic Cooperation (2020), the statistics show that the tendency of Islamic countries and the context of economic cooperation between them has a positive approach; In a way, economic cooperation has been on the rise. According to statistics, intra-organizational trade in exports (meaning the amount of exports that Islamic member countries have with each other) has been steadily increasing from \$ 254 million in 2016 to $\$ 331$ million in 2019. (OIC, 2020).

\section{- Figure 1 Intra-OIC Merchandise Trade (US\$ Billion)}

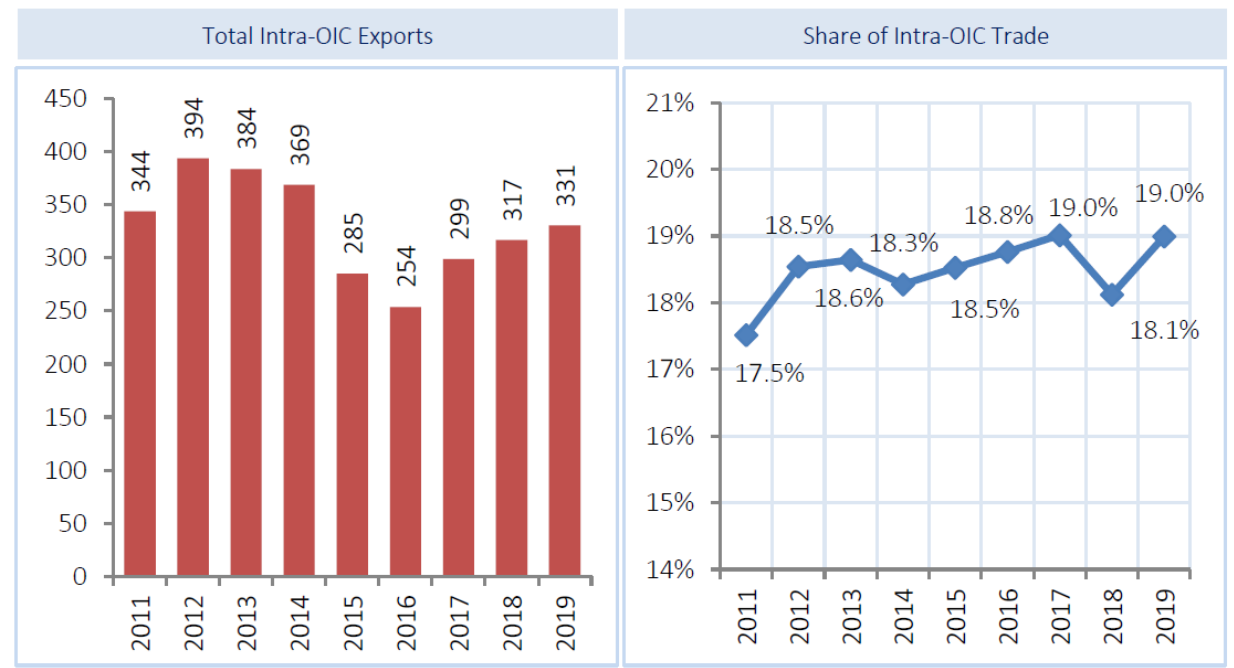

Source: IMF Directions of Trade Statistics (DOTS), July 2020. Data coverage: 56 OIC countries.

According to statistics, in-house trade in the import sector (meaning the amount of imports that Islamic member countries have with each other), in 2019, the UAE with 37.2 billion US dollars in total volume and 11.7 percent of the total, the largest the importer was a member of the Organization of Islamic Cooperation. It is followed by Turkey with $\$ 26.2$ billion and $8.2 \%$ and Kuwait with $\$ 25.1$ billion and $7.9 \%$ (OIC, 2020). 
Figure 2 Intra-OIC Merchandise Exports and Imports (2019, US\$ Billion)
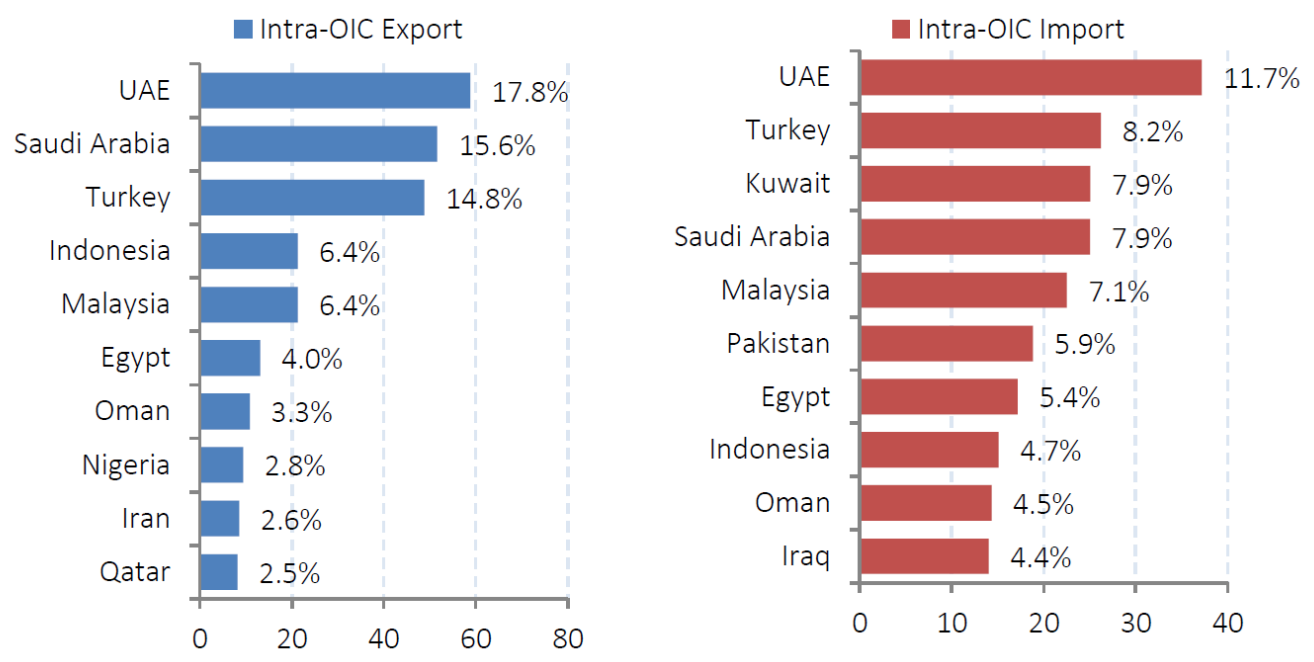

Source: IMF Directions of Trade Statistics (DOTS), July 2020. Data coverage: 56 OIC countries.

Therefore, this shows that the member countries of the Organization of Islamic Cooperation have a large volume of trade in the field of economics.

Therefore, as mentioned before, according to the theory of communication, increasing the exchanges of countries and communication between nations increases their solidarity, and this ultimately leads to convergence. The more communication there is in the fields of transportation, tourism, postal services, trade and immigration, the closer these communities become to each other, turning to cooperation instead of conflict, and forming security communities. One thing to note here is that Deutsch's proposed integrated security community is impractical due to differences between countries in the Islamic world, but his pluralistic community is not impossible.

\section{Convergence experiences}

Since the establishment of the nation-state system in the Islamic lands, various plans for convergence have been proposed, some of which have been implemented and others have remained as proposed. Of the projects that have been implemented, some have failed and others have continued their activities in the hope of future success. Here, only in the form of a headline are these measures taken in two categories to converge in the Islamic world; One is the formation of political alliances and coalitions, including four examples, including the United Arab Republic, the Arab Federation, the Arab League, and the Organization of the Islamic Conference. The other is the formation of economic unions, which includes four items, including the Persian Gulf Cooperation Council, the Arab Cooperation Council, the Group of Eight, and the Economic Cooperation Organization (ECO). Some of these measures can be applied to the theory of federalism, some to the theory of communication and some to the theories of functionalism and neo-functionalism (Velayati and Saeed Mohammadi, 2010). 


\section{The unity of the Islamic ${ }^{1}$ Ummah and the countries of the Islamic world}

Ummah means the collective existence of people; That is, a group in which there are relationships and connections between its members based on a set of thoughts, ideals and principles, and these common connections connect them in some forces and talents. This is a society that the Qur'an has interpreted to the ummah (Azin and et al, 2014). The word ummah has also been used by some Islamic thinkers in a sense close to the nation. Naturally, in this application, the ummah refers to a large group of people who have the same language as the same religion or the same geographical land (Ebrahimi, 1998: 103).

The unity of the Islamic Ummah means the realization of Islamic unity in the whole of the Islamic Ummah. throughout the Islamic world; In a way that ultimately promises the formation of a single Islamic ummah. according to Surah Al-Mu'minun, verse 52 of the Qur'an, it says: "And this is your ummah; The only nation and I am your Lord. "Fear me." In Islam, unity never means abandoning other religions. According to Asura Hajj, verse 78, Islamic unity will be the use of the means of realizing a single nation, as an ultimate ideal, at the level of societies and the Islamic world. Policies are the adoption of unified methods, the use of common facilities and measures that result in the realization of Islamic unity (Azin \& et al, 2014). From the perspective of Quranic verses, the unity of the word of the Muslim Ummah is religious and Islamic unity and is considered as a method and tool and the realization of religious and divine goals and intentions (Azin \& et al., 2014). Therefore, unity is a desirable thing from a religious point of view and it has been highly recommended and emphasized; In such a way that the establishment of religion is in the light of the unity of the Muslim Ummah. This unity is called political unity in the realm of Islamic governments and societies and among Muslim nations (Fouladi, 2008). The unity of the Islamic Ummah means its realization in the whole of the Islamic Ummah and throughout the Islamic world in such a way that it ultimately promises the formation of a single Islamic Ummah. In fact, it is not possible to exclude other religions from unity; Rather, Islamic unity will be the use of the torment of the realization of a single nation as a final ideal at the level of societies and the Islamic world. Therefore, the main and real basis of the unity of the Salami Ummah is the religion of Islam (Ghasemi and Hosseini, 2013). Therefore, when we talk about the unity of the Islamic world, we mean the unity that exists in the Muslim Ummah, the Muslim community and the entire Islamic world, and no religion will be left out.

The Islamic world in this study refers to the lands where most of its people are followers of Islam; Whether these people live in Islamic countries or in non-Islamic countries and in countries that can be considered Islamic; But so far, they have not joined the Organization of the Islamic Conference. Currently, about sixty independent countries with more than $50 \%$ of their population are Muslims and also Muslim minorities in other countries, constitute the Islamic world, which are geographically spread around the world (Raja, 2012).

When it comes to the unity of the countries of the Islamic world, several definitions appear. Although there are many different definitions of the convergence and unity of the Islamic world, it is obvious that Islamic scholars do not mean the unity of Islamic religions into one religion. Unity means that Muslim sects recognize each other correctly and are aware of each other's intellectual and doctrinal positions, avoid conflict, and stand in a united front against a common enemy. Therefore, Islamic

\footnotetext{
${ }^{1}$ Muslims society
} 
unity, cooperation between followers of Islamic religions based on common and indisputable Islamic principles and taking the same position, in order to achieve the lofty goals and interests of the Islamic Ummah and unity against enemies, while respecting the ideological and practical commitments of every Muslim to Is your religion (Taskhiri, 2008)

Approximation of religions also means bringing Shiite and Sunni followers closer by preserving the unity of both parties, and this invitation is based on science and reason and not on fleeting emotions and feelings (Biazar Shirazi, 2006). In other words, the rapprochement of Islamic religions is the approach of the followers of Islamic religions with the aim of getting to know each other, in order to achieve religious brotherhood based on common Islamic principles and finally cooperation based on these principles, and adopting the same position to achieve the lofty goals of the Islamic Ummah. One is against the enemies of Islam and finally not insulting the leaders and religious principles of other Islamic religions (Asef Mohseni, 2007). The common denominator of the above definitions is the emphasis and understanding on commonalities and the avoidance of divisive and divisive issues. In case of convergence in such a concept, two internal and external effects can be seen. The convergence that takes place within the Islamic world leads to the consolidation of resources and the increase of power and authority of Islamic societies and the maximization of their forces in the path of growth and development. The external effect of this hegemony is to confront the common enemy of Islam and Muslims and face it with one hand and one piece with all capacities and forces (Abbasi, 2015).

The Islamic world now has a set of heterogeneous geopolitical features. The many challenges to the unity of the Islamic world, if properly managed and reduced, can lead to the restoration of the past greatness of Islamic civilization in the geometry of world power. However, the dependence of governments on the West is currently the most important obstacle to the unity of the Islamic world; But the major and prominent role of some regional powers, such as the Islamic Republic of Iran in strengthening Islamic unity should not be overlooked (Azin et al., 2014).

\section{Corona epidemic as a crisis}

This is not the first time the world has faced the challenge of an epidemic. History shows that in the past, diseases such as plague, cholera, typhus, Spanish flu, Asian flu and swine flu have affected many countries of the world and caused the death of thousands of people around the globe. The disease, which has a high rate of transmission and has so far killed thousands of people, is a dangerous threat to human health and has become a crisis due to its prevalence and the lack of ability of countries around the world to deal with this phenomenon. Has been. But as mentioned before, in order for a threat to be considered a crisis, it must have the characteristics of a crisis (it can be considered as a crisis. Therefore, according to what has been mentioned before) We have applied three characteristics of the corona pandemic crisis to the characteristics of the crisis.

\section{The surprise and sudden appearance of a situation}

The new corona virus was first discovered in China in late 2019 and has since become a global epidemic and one of the most difficult human trials in history (World Economic Forum, 2020). On 
January 30, 2020, the World Health Organization announced a new coronavirus and declared a public health emergency. On February 11, 2020, the World Health Organization officially designated the virus as Coronavirus (19 COVID). The disease has been the largest outbreak since the severe outbreak of SARS Acute Respiratory Syndrome in 2003 and has rapidly affected governments and public health systems with the possibility of severe respiratory illness. Millions of lives have changed significantly and a global process is underway. The corona virus has created a general medical crisis that requires an appropriate emergency response. The virus was first identified as an emerging infectious disease in Wuhan, China. Common symptoms include fever, cough, and shortness of breath. Due to the lack of vaccines, non-pharmacological interventions are the only way to prevent the disease, which significantly affects the daily habits of the body, mental condition, social and economic status (WHO, 2020) Unprecedented measures to slow down and stop Coronavirus transmission is performed, which reduces the time and pressure on health systems, but has high economic and social costs. Criteria of social distance, school closures, and work environments challenge individuals and lead to a number of psychological problems that will have long-term effects. And coronavirus disease is now a pandemic. While this pandemic is spreading rapidly around the world, it has caused fear and anxiety in the general public, especially among certain groups, including the elderly, caregivers, health care providers, etc. (Schoch- Spain, 2020). Although some scientists and researchers, such as Frederick J. Cassels, believe that the disease was not a surprise, on a large scale, it has emerged for the whole world and has brought different shocks to the world. The following is a brief reference to them;

The sudden onset of this disease shocked the world a lot. One of the most important effects of this virus is the shock of the global economy. The Organization for Economic Co-operation and Development (OECD) has warned that some of the world's major economies will enter recession in the coming months and it will take years for the coronavirus to recover (Hutt, 2020). Another impact that Corona has had on the world is the shock to the market and the workforce. The coronavirus epidemic has created a gap between employees and offices and factories; Some did not show up for work and some were fired by their employers. The virus has had a profound effect on the world's workforce. In March, for example, some airlines asked their employees to either go on unpaid leave or enroll in redundancy programs. Organizations around the world need to accept the new fact that they no longer have the number of employees they already have, or simply cannot expect employees to be able to travel on a daily basis in ways that they are likely to. Puts you at risk for coronavirus. With the crisis created for businesses such as hotels, restaurants, tourism, etc., the unemployment trend has accelerated. What makes this crisis different from other crises is the speed of this crisis. During the recession of 2008, the unemployment rate in the United States was twice as high as it is now, but in this year's crisis, the rate of these claims is much higher (Manti, 2020).

\section{Endangering important goals or threatening core values}

The most important thing that the Corona pandemic targets is human security, the most important dimension of which is human health and survival. The virus has killed many people so far and has spread all over the world with its high speed of transmission. Until the vaccine is discovered, the only recommended ways from the World Health Organization and the health ministries of each country are to wear a mask, keep a distance, stay at home and take care of your health. 
The coronavirus epidemic is still spreading. In more than 175 countries, outbreaks of the virus have been reported, and by March 30, the number of registered cases of the virus had reached more than 735,000 , of which 35,000 had died. (Craven \& et al, 2020). According to new statistics, by November 11, 2020, the number of coronavirus patients in the world has reached 39 million 176 thousand 103 people and the death of 1 million 102 thousand 946 people has been confirmed due to this disease (donya-e-eqtesad, 2020).

\section{Time constraints and decision making by the main decision makers of the unit involved in the} crisis

One of the most important characteristics of any crisis is time constraints. Time constraints lead to governments and countries failing to make timely and appropriate decisions in the face of crisis. However, the question is, where does this time constraint come from? The answer is clear; Secrecy. The Associated Press investigative report, based on internal documents from the World Health Organization and witness testimony, shows that Chinese authorities did not release the genetic map or genome of the new corona virus to the world until a week after it was decoded. They were two weeks late. According to an Associated Press investigation report, while scientists at the Wuhan Institute of Virology on January 2 determined the genetic sequence of the virus, Chinese officials did not release the information until more than a week later, on January 12. It also took January 20 for the Chinese government to notify the World Health Organization and other countries that the virus could be transmitted to humans. The Chinese government launched the official announcement just one day after laboratory researchers in Shanghai led by Zhang Yongzhen released the information. The World Health Organization at the time praised the Chinese government for its swift response to the outbreak. But officials at the time were privately expressing concern that China had withheld basic information about the virus. Internal documents from the World Health Organization show that the organization had repeatedly complained about China's failure to release data quickly and was concerned about being blamed for the late response to the deadly virus outbreak. According to the Associated Press of the National Health Commission, China's top health official had blocked the release of information about the new corona virus by the laboratory without prior approval, thus providing vital information about the virus to other countries with a delay for most of January. (Hamshahrionline, 2020). Therefore, the time limit was a very important factor that led to the crisis of the corona due to the late notification of the Chinese authorities. Therefore, according to what has been mentioned before, any threat that has three characteristics of a crisis can be considered as a counter to a crisis. These features were adapted for the Corona pandemic, and it became clear that the pandemic had become a crisis.

\section{The role of Corona in the unity of the countries of the Islamic world}

With the outbreak of coronation, countries in the Islamic world and religious groups have reacted differently to the disease. ISIL has ordered its followers not to travel to Europe, which is the center of the disease. Conservative Sunni clerics have proposed conspiracy theories, blaming Shiites and atheists for the global pandemic. Some clerics in Egypt, Iraq, Jordan and Morocco even discussed whether this outbreak of divine punishment is against the infidels. Moderate Islamist parties cooperated with governments and provided practical advice to followers on how to prevent the virus (Andrew Hanna, 2020). Therefore, it is clear that there are different views on the corona crisis in 
Islamic countries and the Islamic world, but the main question that this study seeks to find is the role of the corona in the unity of the countries of the Islamic world. Does the corona have a role in the unity of the countries of the Islamic world?

As mentioned earlier, Islam places great emphasis on the unity of Muslim countries and always reminds Muslims of unity and solidarity in the face of various issues. Therefore, it is expected that the countries of the Islamic world will cooperate with each other in dealing with this crisis and take important and strong steps towards unity. However, has this really happened? There is not enough information and data to answer this question. It seems that the only data that can be examined and can answer the main research question is the International Conference on Islamic Unity (focusing on Islamic cooperation in the face of disasters) and the report of the Organization of Islamic Cooperation (OIC).

The focus of the report is on the Islamic Cooperation Organization, trade and economy, and financial relations between Islamic countries, as well as the effects of the corona on the economies of the Islamic world. The report states that countries have adopted protectionist trade policies in response to the urgent need for personal protective equipment and medical equipment, indicating that many countries around the world, as well as Islamic countries and the Islamic world, are cautious. And tried to stop the virus by restricting exports and imports. Therefore, it seems that this way has been more about protecting the interests of countries than trying to cooperate and unite.

At the 34th Conference on Islamic Unity (1Nov 2020), which was held virtually, various Islamic scholars and political and religious figures each delivered speeches, emphasizing the need for unity of Islamic countries and the Islamic world and Muslims. They can get good information;

Mawlawi Mohammad Mokhtar Mofleh stated: I believe that the most important strategy for Islamic unity and the fight against Corona is meditation and emphasis on a common jurisprudential basis among Muslims, which will provide a suitable platform for the rapprochement of Islamic religions (iqna, 2020).

Abdul Rashid Omar, a researcher in Islamic studies from South Africa, said: "The corona pandemic has created difficult and exhausting conditions for everyone. But the very positive and compassionate approach taken by most of the leaders of Islamic countries, Islamic organizations and believers is encouraging. He added: "It is reassuring and encouraging that the majority of Muslims have agreed to turn their homes into places of worship, and this is a positive sign that Muslims are capable of accepting a change in circumstances." Pointing out that the Corona Pandemic will unfortunately be with us for a long time, Omar said: "It is necessary for Muslim scholars, especially the jurists of Islam, to be creative in extracting the rich resources of the great legal heritage of Islam in order to respond to the crises of the mehrnews, 2020).

Sheikh Ismail Doa, President of the Supreme Council of Muslims of Zimbabwe, said: "In Zimbabwe, the Supreme Council of Islamic Affairs, which is responsible for coordinating the activities of Islamic organizations, immediately took responsibility for protecting believers and began working with a corona working group of specialists and religious leaders." The working group cooperates with the Ministry of Health Working Group set up by the President of Zimbabwe. This working group has reviewed and identified all aspects of the Islamic lifestyle and how to change it in order to better coordinate preventive measures to control the spread of the corona virus. Noting that the working 
group also addresses the religious issues of the Zimbabwean people, including congregational prayers and religious ceremonies, he expressed satisfaction that the Zimbabwean Supreme Council of Islamic Affairs has been largely successful in combating coronary heart disease among the country's Muslims. Ismail Doa called on Islamic organizations to provide facilities to poor countries such as Zimbabwe, and to share their information and resources to fight the corona. At the end of his speech, he emphasized: "We believe that the work that has been started to fight Corona can achieve the desired result with the help of other Muslims and Islamic organizations around the world and save people from death in the hope of God" (mehrnews, 2020) .

"Many cases have been affected by the outbreak of the corona epidemic around the world," said Dr. Zahed Ali Zahed, a professor and former dean of the Faculty of Islamic Sciences at Karachi University. Many of the scientific activities that were taking place around the world were certainly influenced by it. He added: "They will find a solution to every problem. For scientific activities, seminars, conferences and workshops or other aspects of education and teaching, a solution has been found, and this solution is to have webinars and conferences online instead of seminars." Is. Dr. Zahed stated: "Virtual scientific activities continue to some extent, although due to their absence, it does not bring all the benefits it brings to humans." But it is definitely accepted as a solution. Referring to the theme of the International Conference on Islamic Unity, he noted: "First of all, there are epidemics like the corona in the world and such natural disasters have occurred in various forms, sometimes earthquakes, sometimes storms, sometimes rain and floods. Many people die. Speaking of the Islamic Ummah, we see that most Islamic countries are in the Third World group, where there is a severe shortage of basic necessities, poverty, ignorance, disease and unemployment. When it comes to the coronavirus, we see that many Muslim countries have been severely affected and do not have the health facilities to fight this deadly disease. He added: "So there is a need for a link between the Islamic world, a chain through which Muslim countries can help each other, where there is a need for cooperation in other areas, and health, it is very important." Although the disease has no religion and the disease does not allow anyone to come, the discussion of cooperation is where other nations of the world exist. Where countries work together. Dr. Zahed emphasized: Therefore, Muslim countries should cooperate with each other like other fields in the field of education, culture, and health policy (iuc.taqrib, 2020). Therefore, according to the findings, it can be inferred that the corona did not play a significant role in the unity of the countries of the Islamic world.

\section{Conclusion}

With the spread of the coronavirus in the world, a new era emerged in the foreign policy of governments and the importance of cooperation and unity in the face of a global epidemic for governments became more prominent. The disease, which also has a high rate of transmission, has spread to most parts of the world, affecting all countries of the world. The countries of the Islamic world are also involved in this crisis, each of which is facing this crisis according to its own circumstances. The countries of the Islamic world also realized that the way to deal with this disease, in addition to the special facilities and capacities that each country applies in the face of it, requires more cooperation, but according to the research findings, Islamic countries and countries of the Islamic world They only emphasized the solidarity and sympathy of the countries of the Islamic world theoretically. In fact, they potentially emphasized cooperation and unity, but in practice, no activities 
based on cooperation and unity have been observed. Also, due to the characteristics of this crisis, countries are more seeking to equip and strengthen themselves, and according to the Organization of Islamic Cooperation, Islamic countries continue to try to advance the economy through the economy and the implementation of restrictive trade and financial policies. They have their own country to be able to face this crisis.

\section{References}

Abbasi, Safar (2015). Convergence and unity of the Islamic world, Journal of Religious Epistemology in the International Field V 3, N 8, 73_100. \{in Farsi \}.

Abedi Ahmad, Shawakhi Alireza (2010). Comparison of quantitative and qualitative research methodology in behavioral sciences, Strategy, V 19, N 54, 153_168. \{in Farsi\}.

Asef Mohseni, Mohammad (2007). Approximation of religions from view to action, Qom: Publication of religions.

Azin, Ahmad; Ghaedi, Mohammad Reza; Golshani, Alireza (2014). Unity of the Islamic world from Imam Khomeini's point of view, Political studies, V 6, N 23, 187_208. \{in Farsi\}.

Bi Azar Shirazi, Abdolkarim (2006). Islam, the Religion of Solidarity, Tehran: Besat Publishing. \{in Farsi $\}$.

Brecher, M and J Wilkenfeld (1988). Crisis in the Twente century. In handbook of international crisis, oxford: Pergamon press.

Deutsch,k,w (1979). Tides among nations. New York: free press.

Deutsch,k,w (1969). Nationalism and social communication, Cambridge, MIT press.

Deutsch, k,w (1957). Political community and the north Atlantic area, Princeton.

Fouladi, Mohammad (2008). The strategy of the unity of the Islamic world in Imam Khomeini's thought, Maaref Monthly, V17, N 3, \{in Farsi \}. magiran.com/p515677.

Frankel, Joseph (2000). Theories of International Relations, translated by Vahid Bozorgi, Tehran: Information Publications. \{in Farsi \}.

Ghasemi, Zahra and Hosseini; Seyed Mohammad Amin, (2013). The place of unity and cohesion in Islam with emphasis on the view of the Supreme Leader, Bi-Quarterly Journal of Islam and Social Sciences, V 5, N 9, \{in Farsi \}. magiran.com/p1264215.

Goli Zavareh, Gholamreza (2006). Geography of the Islamic World: Familiarity with Islamic Countries and the Realm of Muslim Minorities, Qom: Imam Khomeini Educational and Research Institute Publishing Center. \{in Farsi\}.

Hafeznia, Mohammad Reza (2000). Fundamentals of Political and Social Studies (2), Qom: Organization of Schools Abroad. \{in Farsi $\}$. 
Kazemi, Ali Asghar (1991). Convergence Theory in International Relations, Tehran: Qoms Publishing. \{in Farsi $\}$

Manti, Hossein (2020). A study of the effects of the Corona-Covid virus on the global economy, Social Impact Assessment Quarterly, V 1, N 2, 163_181. \{in Farsi \}.

Mostaghimi, Bahram (1994). On the definition of crisis in the international system. Faculty of Law and Political Science, 169_204. \{in Farsi\}

Mottaqi, Afshin; Rahimi, Raouf; Ayvazlou, Mahmoud (2015). The strategic role of the Silk Road in cultural development and the consolidation of a resistance economy, Maarefat, V 24, N 212, 57_72. \{in Farsi $\}$

Rassoli Sani Ababdi, Elham (2013). An introduction to the most important concepts and terms of international relations, Tehran: Tisa. \{in Farsi $\}$

Raja, Ali Asqar (2012). The Criteria of the Definition of Muslim World, Marifat,V 20 ,N 11, 31. \{in Farsi \}. magiran.com/p977431

Rosenthal, U (1988). Crisis management: An introduction perspective, Brussels: international institute of administrative science.

Rosenthal, Ariel; Hart, Paul T; Charles, Michael T (2002). A World of Crisis and Crisis Management, Translated by Mohammad Ali Sattari Faghihi, Law Enforcement Research Quarterly, 4 (4), 118_140

Rosental, U and L Comfort (2001). Manag,ent crisis: threats dilemas opportunity, spring field: cgarls Thomas publisher.

Taskhiri, Mohammd Ali (2008). Talks about the approximation of religions, Thought of approximation, V 4, N 14, 7_40. \{in Farsi\}

Tylor, Paul (1968). The Functionalist approach to the problem of international order: a defence political studies. XVI, 3.

Velayati, Ali Akbar; Saeed Mohammadi, Reza (2010). Analysis of Convergence Experiences in the Islamic World, Political knowledge, V 6, N 1, 151)179. \{in Farsi \}

Yousof zadeh, Hassan and Khavari, Hasan Reza (2019). An Introduction to the Theology of Convergence in the Islamic World. Journal of Islamic Humanities, V 6, N 11, 99_125. \{in Farsi\}.

\section{Internet resources}

Craven, Matt, Linda Liu, Mihir Mysore, Shubham Singhal, Sven Smit, and Matt Wilson (2020); COVID-19: Implications for business; https://www.mckinsey.com/businessfunctions/risk/our-insights/covid-19-implications-for-business

Hanna, Andrew (2020). What Islamists Are Doing and Saying on COVID-19 Crisis. https://www.wilsoncenter.org/article/what-islamists-are-doing-and-saying-covid-19-crisis 
Hutt, Rosamond (2020). The economic effects of covid 19 around the world;

http://www.wweforum.org./agenda/2020/02/coronavirus-economic-effects-global-economytrade-travel/

OIC (2020). OIC ECONOMIC OUTLOOK 2020; Trade and Integration Challenges amid Rising Uncertainties, Turkey: Statistical, Economic and Social Research and Training Centre for Islamic Countries (SESRIC).

Schoch-Spana, Monica (2020). Covid-19's psycholocial impacts the pandemic is putting enormous stress on all of us but especially on health care workers and other specific groups. Scientific American march 20.2020. http://blogs.scentificamerican.com

World Economic Forum (2020); Strategic Intelligence: COVID-19; https:// intelligence.weforum.org.

World Health Organization. (2020). Mental health and psychosocial considerations during the COVID-19 outbreak. https://www.Who.int.

_ (2020). The latest statistics of coronary heart disease in the world / death of more than one million people in the world, available in https://donya-e-eqtesad.com.

_ (2020). Leaked documents show China's secrecy at the beginning of the Corona outbreak, available in www.hamshahrionline.ir.

_ (2020) Analysis of the most important strategy of Islamic unity and struggle against Corona, available in www.iqna.ir.

_ (2020). Corona is an opportunity to increase empathy and synergy among Muslim nations, available in www.mehrnews.com.

_ (2020). Karachi University Professor at Islamic Unity Conference: Corona is not Divine Punishment / Islamic Countries Must Work Together to Deal with Corona, available in http://iuc.taqrib.ir/. 